\title{
Orientasi Religiusitas dan Efikasi Diri dalam Hubungannya dengan Kebermaknaan Pendidikan Agama Islam pada Mahasiswa IAIN Palopo
}

\author{
Hisban Thaha dan Edhy Rustan \\ Institut Agama Islam Negeri Palopo \\ edhy_rustan@iainpalopo.ac.id
}

\begin{abstract}
This research aims to find out the influence of religious orientation and self efficacy on the meaning of Islamic education. Technique of data analysis of this research use correlation and regression statistic test conducted by IAIN Palopo student with 75 respondents. The design of this research is the correlation design between the relation of religiosity orientation with the meaning of Islamic religious education, the relationship of self efficacy with the meaning of Islamic religious education, and the relation of religious orientation and self efficacy to the meaningfulness of Islamic religious education. After the research done by spreading the questionnaire, it was found that the orientation of religious self efficacy had an effect on the meaning of Islamic education either simultaneously or partially. Reflective contribution for religious orientation was $41,51 \%$, and self efficacy was $58,49 \%$, while for the effective contribution of religious orientation variable was $2.99 \%$, and self efficacy variable was $4,21 \% .4,6 \%$ variation meaningfulness Islamic education can be explained by the orientation of religiosity and self efficacy, while the remaining $95,4 \%$ is explained by other factors.
\end{abstract}

Keywords: Orientation of religiosity, Self efficacy, Faithfulness Islamic Education

\section{A. Pendahuluan}

Kebermaknaan Pendidikan Agama Islam (PAI) merupakan kualitas penghayatan individu terhadap seberapa besar ia dapat mengembangkan dan mengaktualisasikan ajaran Islam yang berupa bimbingan dan asuhan agar senantiasa memahami, menghayati, dan mengamalkan ajaran agama Islam yang telah diyakininya secara menyeluruh, serta menjadikan agama Islam itu sebagai suatu pandangan hidupnya demi keselamatan dan kesejahteraan hidup di dunia maupun di akhirat. Agama adalah fitrah dan penting bagi kehidupan manusia karena agama merupakan sumber sistem nilai, petunjuk, pedoman, bagi manusia untuk memecahkan berbagai masalah dalam hidup sehingga terbentuk motivasi, tujuan hidup dan perilaku manusia yang lebih baik. Salah satu faktor pendorong terwujudnya agama adalah melalui pendidikan, karena pendidikan agama dapat membina dan mengembangkan pribadi manusia. 
Muhaimin berpendapat bahwa pendidikan agama Islam bermakna upaya memberikan ajaran Islam dan nilai-nilainya agar menjadi pandangan dan sikap hidup seseorang. Dari aktivitas pendidikan agama Islam itu bertujuan untuk membantu seseorang dalam menanamkan dan/atau menumbuhkembangkan ajaran Islam dan nilai-nilainya untuk dijadikan sebagai pandangan hidupnya. ${ }^{1}$

Lebih lanjut kebermaknaan pendidikan agama Islam sangat dipengaruhi oleh orientasi religiusitas seseorang, dimana orientasi religius merupakan cara pandang individu mengenai agamanya dan bagaimana individu tersebut menggunakan agama atau keyakinannya dalam kehidupan sehari-hari. Menurut Allport dan Ross "Religius orientation has been defined as the extent to which a person lives out his or her religius belief'. ${ }^{2}$ Hubungan ini dipengaruhi karena pendidikan agama Islam menyentuh seluruh aspek kepribadian, baik batiniah (mental atau spiritual) maupun tingkah laku fisik.

Pada dasarnya sikap seseorang sangat erat kaitannya dengan religiusitas. Individu yang mempunyai religiusitas yang baik akan ikhlas menerima apa yang terjadi pada dirinya. Sedangkan individu yang mempunyai religiusitas yang kurang tidak bisa menerima apa yang terjadi pada dirinya. Religiusitas dapat diketahui melalui beberapa aspek penting yaitu aspek keyakinan terhadap ajaran agama (akidah), aspek kekuatan terhadap ajaran agama (syariat atau ibadah), aspek penghayatan terhadap ajaran agama (ihsan), aspek pengetahuan terhadap ajaran agama (ilmu) dan aspek pelaksanaan ajaran agama (amal atau akhlak). Religiusitas bukan hanya penghayatan terhadap nilai-nilai agama saja namun juga perlu adanya pengalaman nilai-nilai tersebut. "Tingkat religiusitas akan senantiasa menyelaraskan segala kehidupan dengan aturan-aturan dalam agamanya. Ia akan patuh dan berfikir positif bahwa segala sesuatu yang telah ditetapkan oleh Allah harus dilaksanakan. ${ }^{3}$

\footnotetext{
${ }^{1}$ H. Muzayyin Arifin, "Filsafat Pendidikan Islam," n.d., 12, accessed November 29, 2017.

2 John McCormick \& Hoekman Denis Catherine \& Smith, "Religious Orientation \& Locus of Control in an Australian Open Enrolment Christian School," Mei 2015, Publikasi Online dari : http://www.aare.edu.au/00pap/mcc00072-.htm.

${ }^{3}$ Nani Sri Handayani and Zahrotul Uyun, "Pengaruh Tingkat Religiusitas Terhadap Kesiapan Menghadapi Perkawinan Mahasantri Pondok Muhammadiyah Hajjah Nuriyah Shabran Surakarta," December 2004, 201 - 228, http://publikasiilmiah.ums.ac.id:80/handle/11617/1056.
} 
Selain sebagai pandangan hidup kebermaknaan PAI juga sangat erat kaitannya dengan efikasi diri. Efikasi diri merupakan keyakinan individu mengenai kemampuan dirinya dalam melakukan tugas atau tindakan yang diperlukan untuk mencapai hasil tertentu. ${ }^{4}$ Karena agama dapat memberikan jalan kepada manusia untuk mencapai rasa aman dan menghindari rasa cemas dalam menghadapi masalah hidup. Sehingga apabila dihadapkan pada suatu dilema atau konflik individu akan menggunakan pertimbangan-pertimbangan berdasarkan nilai-nilai dari agama, di manapun orang tersebut berada dan pada kondisi apapun. Agama dapat menstabilkan perilaku dan menerangkan mengapa dan untuk apa seseorang itu berada di dunia serta menawarkan perlindungan dan rasa aman.

\section{B. Kajian Pustaka}

\section{Orientasi Religiusitas}

Orientasi religius adalah cara pandang individu mengenai agamanya dan bagaimana individu tersebut menggunakan agama atau keyakinannya dalam kehidupan sehari-hari. Dalam kamus psikologi, religion (agama) adalah suatu sistem yang kompleks dari kepercayaan, keyakinan, sikap-sikap, dan upacaraupacara yang menghubungkan individu dengan satu keberadaan atau makhluk yang bersifat ketuhanan. ${ }^{5}$ Batson dan Ventis juga mengemukakan bahwa orientasi religius adalah istilah yang digunakan oleh para psikolog untuk mengarahkan kepada bagaimana individu mempraktikkan atau hidup dengan keyakinan dan nilai-nilai agamanya (religius orientation is the term employed by psychologists to refer to the way in which a person practices or lives out his or her religius belief and values). ${ }^{6}$

Allport dan Ross tipe orientasi religius dapat dibagi menjadi dua, yaitu orientasi religius instrik dan orientasi religius ekstrinsik. Menurut Crapss (1993) orientasi religius instrik adalah agama yang dihayati dan dipandang bernilai bagi

\footnotetext{
4 Jess Feist Winkler-Herman Gregory J Feist Dr., Tomi-Ann Roberts, "Theories of Personality," n.d., accessed November 29, 2017.

5J.P. Chaplin, "Kamus Lengkap Psikologi," accessed November 29, 2017 , http://library.um.ac.id/free-contents/index.php/buku/detail/kamus-lengkap-psikologi-j-p-chaplinpenerjemah-kartini-kartono-31745.html.

${ }^{6}$ Batson Ventis, "Religious Orientation and Meaning in Life: An Exploratory Study," Mei 2015, http://clearinghouse.missouriwestern.-edu/manuscripts/172.php.
} 
dirinya sendiri, yang menuntut keterlibatan dan mengatasi kepentingan sendiri. Bagi individu tersebut agama sudah menyatu dan tidak terpisahkan dengan kehidupan. Individu yang berorientasi religius instrinsik menerapkan atau menjalankan ajaran agama dalam kehidupannya secara konkret. Allport menyatakan bahwa agama semacam ini adalah religi yang dewasa atau mengandung keinginan untuk suatu komitmen yang merupakan penggabungan yang ideal dari hidup individu. Bagi individu agama sudah menyatu dan tidak terpisahkan dengan kehidupan. ${ }^{7}$ Menurut Ventis individu yang berorientasi religius interinsik akan menganggap keyakinan agama sebagai tujuan itu sendiri. Keyakinan agama mereka membantu mengintegrasikan kepribadian mereka dan menghasilkan moralitas yang konsisten. ${ }^{8}$

Allport dan Ross menjelaskan bahwa individu yang menganut orientasi religius ekstrinsik akan memandang agama dalam rangka kegunaan untuk berbagai hal, antara lain untuk memperoleh rasa aman, penghiburan, pembenaran diri, memperbaiki status, dan bertahan melawan kenyataan atau memberi sanksi pada suatu cara hidup. Bagi mereka, keyakinan yang dipeluknya cenderung dianut atau dilambangkan secara selektif agar cocok dengan kebutuhan-kebutuhannya yang lebih primer. Individu dengan orientasi ini cenderung memanfaatkan agamanya demi kepentingan sendiri. Dengan begitu, dapat dikatakan bahwa individu yang berorientasi ekstrinsik "memanfaatkan agamanya". ${ }^{9}$ Lebih lanjut, Hardjana mengemukakan bahwa orientasi religius ekstrinsik adalah iman yang tidak menyatu dengan pribadi orang yang beragama. Baginya iman merupakan masalah luar yang tidak mempengaruhi cara berpikir, berkehendak, dan berperilaku. Orang yang berorientasi religius ekstrinsik bukan menghayati tetapi menggunakan iman demi kepentingan pribadi, ekonomi, sosial yang ada di luar kepentingan iman. Bagi individu semacam ini, menganut agama adalah cara untuk mendapatkan kehangatan, pertolongan dan perlindungan ditengah kehidupan yang

\footnotetext{
${ }^{7}$ Priska N. \& Henny E.W, "Orientasi Religius Pasangan Dewasa Muda Kristen Yang Mengalami Ketidakharmonisan Pernikahan," ARKHE : Journal Ilmiah Psikologi Tahun 9, no. 2 (n.d.).

${ }^{8}$ Winkler-Herman, "Theories of Personality."

${ }^{9}$ Nashori Fuad, “Orientasi Keagamaan Mahasiswi Muslim Berjilbab,” Psikologika 03, no. No.5 (1998).
} 
tidak menentu ${ }^{10}$

\section{Efikasi Diri}

Efikasi diri (self-efficacy) pertama kali diperkenalkan oleh Bandura. Beliau mendefiniskan bahwa efikasi diri adalah keyakinan individu mengenai kemampuan dirinya dalam melakukan tugas atau tindakan yang diperlukan untuk mencapai hasil tertentu. Lebih lanjut Woods menjelaskan bahwa efikasi diri mengacu pada keyakinan akan kemampuan individu untuk menggerakkan motivasi, kemampuan kognitif, dan tindakan yang diperlukan untuk memenuhi tuntutan situasi. ${ }^{11}$ Meskipun Bandura menganggap bahwa efikasi diri terjadi pada suatu kemampuan fenomena situasi khusus, para peneliti yang lain telah membedakan efikasi diri khusus dari efikasi diri secara umum atau generalized self-efficacy. ${ }^{12}$ Efikasi diri tidak berkaitan dengan kecakapan yang dimiliki, tapi berkaitan dengan keyakinan individu mengenai hal apa yang dapat dilakukan dengan kecakapan yang ia miliki seberapa pun besarnya. ${ }^{13}$

Seseorang dengan efikasi diri percaya bahwa mereka mampu melakukan sesuatu untuk mengubah kejadian-kejadian di sekitarnya, sedangkan seseorang dengan efikasi diri rendah menganggap dirinya pada dasarnya tidak mampu mengerjakan segala sesuatu yang ada disekitarnya. Dalam situasi yang sulit, orang dengan efikasi yang rendah cenderung mudah menyerah. Sementara dengan orang dengan efikasi diri yang tinggi akan berusaha lebih keras untuk mengatasi tantangan yang ada. Hal senada juga di ungkapkan oleh Gist, yang menunjukkan bukti bahwa perasaan efikasi diri memainkan satu peran penting dalam mengatasi memotivasi pekerja untuk menyelesaikan pekerjaan yang menantang dalam kaitannya dengan pencapaian tujuan tertentu. ${ }^{14}$

${ }^{10}$ Harjana dalam Toifur, \& Johana Endang P, "Hubungan Antara Status Sosial Ekonomi, Orientasi Religius, Dan Dukungan Sosial Dengan Burnout Pada Guru Sekolah Dasar Di Kabupaten Cilacap," Sosiohumanika, no. 03 (2003).

${ }^{11}$ A. Bandura, Self-Efficacy: The Exercise of Control (New York: W.H.Freeman and Company, 1997).

12 R.Hogan Robbert \& B.W, Personality Psychology: In the Workplace (Washington DC: American Psychology Association, 2001).

${ }^{13}$ Bandura, Self-Efficacy: The Exercise of Control.

${ }^{14}$ Robbert, Personality Psychology: In the Workplace. 
Menurut Bandura, efikasi diri pada diri tiap individu akan berbeda antara satu individu dengan yang lainnya berdasarkan tiga dimensi, yaitu tingkat, kekuatan, dan generalisasi. Dimensi tingkat berkaitan dengan derajat kesulitan tugas ketika individu merasa mampu untuk melakukannya. Dimensi ini memiliki implikasi terhadap pemilihan tingkah laku yang dirasa mampu dilakukannya dan menghindari tingkah laku yang berada di luar batas kemampuan yang di rasakannya. Dimensi kekuatan berkaitan dengan tingkat kekuatan dari keyakinan atau pengharapan individu mengenai kemampuannya. Dimensi ini biasanya berkaitan langsung dengan dimensi level, yaitu makin tinggi level taraf kesulitan tugas, makin lemah keyakinan yang dirasakan untuk menyelesaikannya.

Selanjutnya dimensi generalisasi berkaitan dengan luas bidang tingkah laku yang mana individu merasa yakin akan kemampuannya. Individu dapat merasa yakin terhadap kemampuan dirinya. Apakah terbatas pada suatu aktivitas dan situasi tertentu atau pada serangkain aktivitas dan situasi yang bervariasi. ${ }^{15}$

Terkait dengan kebutuhan kajian ini, efikasi diri dapat diartikan sebagai dorongan terhadap kebermaknaan PAI dalam kehidupan akademik maupun masyarakat. Dorongan yang dimaksud dapat berupa keyakinan dalam menghadapi kesulitan-kesulitan hidup sebagai mahasiswa, untuk memenuhi tuntutan situasi zaman. Dengan mengaktualisasikan pemahaman yang diperoleh melalui pendidikan agama Islam dibangku kuliah, mahasiswa tidak akan terjerumus dalam perilaku atau aktivitas yang melanggar atau bertentangan dengan ajaran agama.

\section{Kebermaknaan Pendidikan Agama Islam}

Makna hidup merupakan sesuatu yang dianggap penting dan berharga, serta memberikan nilai khusus bagi seseorang. Makna hidup bila berhasil ditemukan dan dipenuhi akan menyebabkan kehidupan ini dirasakan demikian berarti dan berharga. Menurut pandangan Frankl (1970) makna hidup harus dilihat sebagai suatu yang sangat objektif karena berkaitan dengan hubungan individu dengan pengalamannya dalam dunia ini, meskipun makna hidup itu sendiri sebenarnya suatu yang objektif, artinya benar-benar ada dan dialami dalam kehidupan. Lebih

${ }^{15}$ Ibid. 
lanjut Frankl (1985) menyebutkan bahwa makna hidup sebagai sesuatu hal yang bersifat personal, dan bisa berubah seiring berjalannya waktu maupun perubahan situasi dalam kehidupannya. Individu seolah-olah ditanya apa makna hidupnya pada setiap waktu maupun situasi dan kemudian harus mempertanggungjawabkan. Menurut Yalom pengertian makna hidup sama artinya dengan tujuan hidup yaitu segala sesuatu yang ingin dicapai dan dipenuhi.

Berdasarkan uraian tersebut dapat disimpulkan bahwa makna hidup adalah hal-hal yang dianggap sangat penting dan berharga serta memberikan nilai khusus bagi seseorang, sehingga layak dijadikan tujuan hidup. Makna hidup ini benarbenar terdapat dalam kehidupan itu sendiri, walaupun dalam kenyataannya tidak mudah ditemukan, karena sering tersirat dan tersembunyi di dalamnya. Bila makna hidup ini berhasil ditemukan dan dipenuhi akan menyebabkan kehidupan dirasakan bermakana dan berharga yang pada giliranya akan menimbulkan perasaan bahagia. Dengan demikian dapat dikatakan bahwa kebahagiaan adalah ganjaran atau efek samping dari keberhasilan seseorang memenuhi makna hidup.

Mengacu pada karakteristik kebermaknaan kehidupan yang ditemukan oleh mahasiswa pada kampus yang berlebelkan Agama Islam khususnya prodi PAI akan memberikan pedoman dan arah terhadap kegiatan-kegiatan yang dilakukannya dalam kegiatan kampus dan masyarakat. Frankl menyimpulkan bahwa makna hidup bisa ditemukan melalui tiga cara, yaitu: nilai kreatif, nilai penghayatan, dan nilai bersikap. Nilai kreatif dapat diraih melalui berbagai kegiatan. Pada dasarnya seorang bisa mengalami stress jika terlalu banyak beban pekerjaan, namun ternyata seseorang akan merasa hampa dan stress pula jika tidak ada kegiatan yang dilakukannya. Kegiatan yang dimaksud tidaklah semata-mata kegiatan mencari uang, namun pekerjaan yang membuat seorang dapat merealisasikan potensi-potensinya sebagai sesuatu yang dinilainya berharga bagi dirinya sendiri atau orang lain maupun kepada tuhan.

Nilai penghayatan menurut Frankl dapat dikatakan berbeda dari nilai kreatif karena cara memperoleh nilai penghayatan adalah dengan menerima apa yang ada dengan penuh pemaknaan dan penghayatan yang mendalam. Realisasi nilai 
penghayatan dapat dicapai dengan berbagai macam bentuk penghayatan terhadap keindahan, rasa cinta dan memahami suatu kebenaran.

Nilai bersikap, nilai ini sering dianggap paling tinggi karena di dalam menerima kehilangan kita terhadap kreativitas maupun kehilangan kesempatan untuk menerima cinta kasih, manusia tetap bisa mencapai makna hidupnya melalui penyikapan terhadap apa yang terjadi. Bahkan di dalam suatu musibah yang tak terelakan, seorang masih bisa dijadikannya suatu momen yang sangat bermakan dengan cara menyikapinya secara tepat. Dengan perkataan lain penderitaan yang dialami seseorang masih tetap dapat memberikan makna bagi dirinya.

\section{Metode Penelitian}

Penelitian ini merupakan penelitian korelasi yang bertujuan untuk mendeskripsikan dan mengukur hubungan orientasi religiusitas dengan kebermaknaan pendidikan agama Islam, serta hubungan efikasi diri dengan kebermaknaan pendidikan agama Islam. Penelitian korelasional menginterpretasi berapa besar dan arah korelasi. Derajat hubungan suatu koefisien korelasi sebesar antara $-1,00$ sampai $+1,00$, dengan 0,00 menunjukkan sama sekali tidak ada hubungan linear. Gravetter dan Wallnu menyebutkan bahwa hubungan diantara dua set skor ini merefleksikan apakah ada hubungan yang konsisten dan dapat diprediksi diantara skor-skor. ${ }^{16}$ Berikut rancangan korelasional dalam penelitian ini.

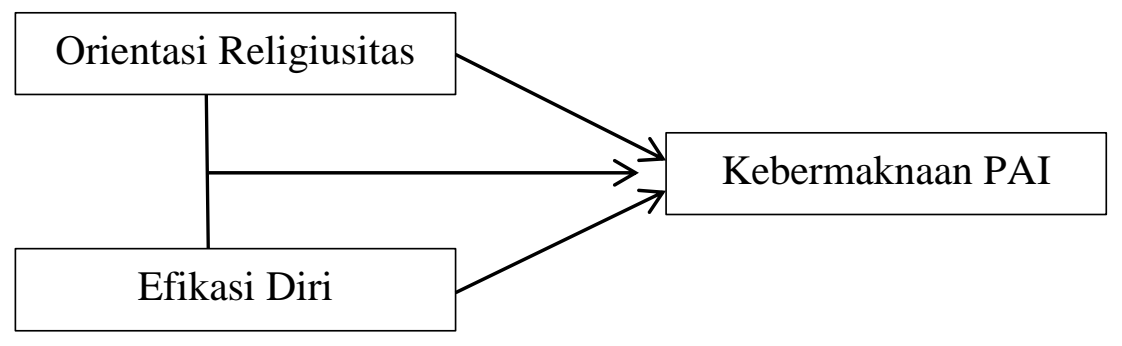

Gambar 1. Rancangan Korelasional

Kebermaknaan pendidikan agama Islam diungkap dengan mengacu pada teori logoterapi Frankl yang mencakup creative values, experenxial values dan

16 John Creswell, Riset Pendidikan (Perencanaan, Pelaksanaan, Dan Evaluasi Riset Kualitatif Dan Kuantitatif (Yogyakarta: Pustaka Pelajar, 2015), 683. 
attitude values. Orientasi religiusitas diungkap dengan mengacu pada teori Allport, yang mencakup orientasi religiusitas intrinsik dan orientasi religiusitas ekstrinsik. Efikasi diri diungkap melalui aspek yang dikemukakan oleh Albert Bandura, mencakup dimensi tingkat (level), dimensi kekuatan (strength) dan dimensi generalisasi (generality)

Populasi penelitian ini adalah seluruh mahasiswa program S-1 IAIN Palopo prodi PAI semester III, V, dan VII. Teknik sampling yang digunakan dalam penelitian ini secara random dengan mengacu pada tabel Krejcie dan Morgan. ${ }^{17}$ Dengan menggunakan tabel tersebut diperoleh sampel sebesar 75 orang. Teknik analisis data penelitian ini menggunakan uji statistik korelasi dan regresi. Metode yang digunakan untuk mendapatkan data dalam penelitian ini adalah dengan menggunakan angket.

\section{Pembahasan}

Analisis deskriptif orientasi religiusitas berdasarkan nilai skor aktual pada menunjukan pada umumnya orientasi religiusitas mahasiswa sebesar 58,33\% jika dikategorikan berada pada level sangat rendah. Dari nilai tersebut indikator intrinsik mempunyai nilai skor lebih tinggi dibandingkan dengan indikator ekstrinsik yaitu sebesar 59,86\% sedangkan indikator ekstrinsik hanya sebesar $56,39 \%$.

Analisis deskriptif variabel efikasi diri mahasiswa mempunyai persentase sebesar 51,01\% jika dikategorikan berada pada level sangat rendah. Dari nilai tersebut indikator dimensi tingkat mempunyai persentase skor sebesar 51,35\% dengan kategori sangat rendah begitu juga dengan dimensi kekuatan dan dimensi generalisasi yang masing-masing sebesar sebesar 55,08\% dan 46,75\%.

Analisis deskriptif variabel kebermaknaan PAI sebesar $71,41 \%$ dalam kategori sangat rendah. Dari nilai tersebut indikator nilai-nilai kreatif mempunyai persentase skor sebesar 57,90\%, nilai-nilai penghayatan sebesar 70,19\%, dan yang terakhir yaitu nilai-nilai perilaku sebesar $62,13 \%$.

${ }^{17}$ Usman Sitiadi Usaini dan Akbar, R. Purnomo, Pengantar Statistika (Jakarta: Bumi Aksara, 1995), 322. 
Uji prasyarat analisis meliputi uji normalitas, multikolinearitas, linearitas, dan autokerelasi. Uji normalitas bertujuan untuk menguji apakah dalam model regresi variabel residual memiliki distribusi normal. Hasil uji normalitas dengan menggunakan Kolmogorov-Smirnov Test untuk orientasi religiusitas sebesar 0,748>0,05, efikasi diri sebesar 0,887>0,05, dan kebermaknaan PAI sebesar $0,760>0,05$, dengan demikian data berdistribusi normal.

Uji multikolinearitas dilakukan untuk mengetahui apakah pada model regresi ditemukan adanya kolerasi antara orientasi religiusitas dan efikasi diri. Hasil perhitungan nilai Variance Inflaion Factor (VIF) diperoleh nilai untuk kedua variabel sebesar 1,573, disimpulkan bahwa tidak ada multikolonieritas antara variabel independen dalam model regresi.

Uji linearitas digunakan untuk melihat apakah spesifikasi model yang digunakan sudah benar atau tidak. Berdasarkan hasil Uji linearitas menggunakan Anova tabel diperoleh harga $f_{\text {hit }}$ kebermaknaan PAI atas orientasi religiusitas sebesar 1,085 lebih kecil dari $\mathrm{f}_{\text {tab }}$ sebesar 3.970 dengan probabilitas sebesar 0,415 lebih besar dari taraf signifikansi 0,05. Ini berarti orientasi religiusitas terhadap kebermaknaan PAI bersifat linier. Selanjutnya harga $f_{\text {hit }}$ ke-bermaknaan PAI atas efikasi diri sebesar 0,722 lebih kecil dari $\mathrm{f}_{\text {tab }}$ sebesar 3.970 dengan probabilitas sebesar 0,809 lebih besar dari taraf signifikansi 0,05. Ini berarti efikasi diri terhadap kebermaknaan PAI juga bersifat linier.

Uji Autokorelasi dimaksudkan untuk mengetahui apakah terjadi korelasi antara residual pada serangkaian observasi tertentu dalam suatu periode tertentu. Menurut Durbin Watson, besarnya koefisien Durbin Watson adalah antara 0-4. ${ }^{18}$ Berdasarkan hasil pengolahan diperoleh nilai statistik Durbin Watson (DW) diperoleh nilai 1,580, nilai tersebut berada pada kisaran $0<\mathrm{DW}<4$ maka dapat disimpulkan tidak terdapat autokorelasi pada model regresi.

Pengujian hipotesis dalam penelitian ini dilakukan dengan memperhatikan nilai thit dari hasil regresi tersebut untuk mengetahui signifikansi variabel independen secara terpisah (parsial) terhadap variabel dependen dengan tingkat kepercayaan $95 \%$ atau pada tingkat $\alpha=5 \%$. Jika nilai signifikansi uji-F, F $<0.05$

${ }^{18}$ Sutrisno Hadi, Statistik Jilid 2 (Yogyakarta: Penerbit Andi, 2000). 
maka terdapat pengaruh antara semua variabel independen terhadap variabel dependen. Berikut hasil $t_{\text {hit }}$ dan $\mathrm{F}_{\text {tabel. }}$

Tabel 1. Nilai koefisien regresi, thitung dan keputusan variabel dependen kebermaknaan PAI

\begin{tabular}{lccccc}
\hline \multicolumn{1}{c}{ Variabel } & Koefisien Regresi & $\mathrm{t}_{\text {hit }}$ & $\mathrm{t}_{\mathrm{tab}}$ & $\mathrm{Sig}$ & Keputusan \\
\hline Orientasi religiusitas & 0,078 & 1,904 & 1,993 & 0,369 & $\mathrm{H}_{0}$ diterima \\
Efikasi diri & 0,208 & 1,193 & 1,993 & 0,237 & $\mathrm{H}_{0}$ diterima \\
\hline
\end{tabular}

Tabel 2. Hasil analisis Uji F

\begin{tabular}{lrrrrr}
\hline Model & Sum of Squares & \multicolumn{1}{c}{ df } & Mean Square & F & \multicolumn{1}{c}{ Sig. } \\
\hline Regression & 499.033 & 2 & 249,517 & 2,787 &, $068^{\mathrm{b}}$ \\
Residual & 6445,953 & 72 & 89,527 & & \\
Total & 6944,987 & 74 & & & \\
\hline
\end{tabular}

a. Dependent Variable: Kebermaknaan_PAI

b. Predictors: (Constant), Efikasi_Diri, Orientasi_Religiusitas

Pengujian hipotesis dalam penelitian ini ada dua, yaitu pengujian hipotesis secara parsial dan simultan. Pengujian hipotesis secara parsial berdasarkan tabel 1, diperoleh variabel orientasi religiusitas dari hasil analisis penelitian ini mempunyai koefisien regresi 0,078 dengan $t_{\text {hit }}=1,904<t_{\text {tab }}=1,993$. Sehingga dapat disimpulkan bahwa orientasi religiusitas berpengaruh terhadap kebermaknaan PAI. Selanjutnya variabel efikasi diri dari hasil analisis penelitian ini mempunyai koefisien regresi 0,208 dengan $\mathrm{t}_{\mathrm{hit}}=1,193<\mathrm{t}_{\mathrm{tab}}=1.993$ ). berdasarkan hasil ini maka dapat disimpulkan bahwa orientasi religiusitas dan efikasi diri mempengaruhi kebermaknaan pendidikan agama Islam.

Pengujian hipotesis secara simultan berdasarkan pada tabel 2 diperoleh $F_{h i t}$ sebesar 2,787 dengan tingkat signifikansi 0,068. Karena probabilitas $(0,068)$ lebih besar dari 0.05 maka model regresi cocok digunakan untuk memprediksi kebermaknaan pendidikan agama Islam atau dapat dikatakan semua variabel independen yaitu orientasi religiusitas dan efikasi diri secara bersama-sama berpengaruh terhadap kebermaknaan pendidikan agama Islam. Sumbangan relatif prediktor orientasi religiusitas berdasarkan hasil analisis sebesar 41,51\%, dan efikasi diri sebesar 58,49\%. Sedangkan sumbangan efektif prediktor orientasi religiusitas sebesar $2,99 \%$ dan efikasi diri sebesar $4,21 \%$. 
Kebermaknaan PAI merupakan hal yang dianggap sangat penting dan berharga serta memberikan nilai khusus bagi seseorang, sehingga layak dijadikan tujuan hidup. Sumanto menyatakan bahwa makna hidup tidak sekedar sesuatu sebagaimana yang kita pikirkan melainkan sebagaimana kita hayati. ${ }^{19}$ Semakin mendalam penghayatan seseorang terhadap perihal kehidupan, makin bermaknalah kehidupannya. Salah satu kenyataan yang terjadi dalam sepanjang sejarah perjalanan umat manusia adalah fenomena keberagamaan atau sering disebut religiusitas. Sepanjang itu pula, bermunculan beberapa konsep religiusitas. Dimana konsep religiusitas sangat berpengaruh terhadap kehidupan personal dan sosial manusia. Selain konsep religiusitas, efikasi diri juga penting dalam eksistensi manusia terlebih lagi dalam masyarakat modern.

Berdasarkan hasil Penelitian pengaruh orientasi religiusitas dan efikasi diri terhadap kebermaknaan PAI mahasiswa IAIN Palopo diperoleh hasil yang sangat mengejutkan dimana variabel dependen (kebermaknaan PAI) dengan menggunakan kerangka teori logoterapi Frankl yang mencakup creative values, experenxial values dan attitude values hanya sebesar 64,94\%, ini berarti kebermaknaan PAI mahasiswa IAIN palopo masih sangat rendah, begitu juga dengan kedua variabel indepen yaitu orientasi religiusitas dengan menggunakan teori Allport yang mencakup orientasi religiusitas intrinsik dan orientasi religiusitas ekstrinsik sebesar 58,33\%. Selanjutnya untuk efikasi diri yang diambil dari teori Albert Bandura, mencakup dimensi tingkat (level), dimensi kekuatan (strength) dan dimensi generalisasi (generality) lebih rendah dari dua variabel sebelumnya yaitu hanya sebesar $51,01 \%$.

Fenomena ini menggambarkan bahwa dunia modern dengan revolusi ilmu pengetahuan dan teknologi yang canggih ternyata telah banyak mengubah perilaku dan budaya masyarakat, termasuk masyarakat pelajar IAIN Palopo. Di satu sisi, masyarakat semakin luas wawasan pengetahuannya namun di sisi lain budaya masyarakat Indonesia yang dikenal sebagai budaya Timur, secara perlahan-lahan telah berubah cenderung mengikuti budaya Barat yang bisa jadi

${ }^{19}$ Sumanto, Metodologi Penelitian Sosial Pendidikan: Aplikasi Metode Kuantitatif Dan Statistika Dalam Penelitian (Yogyakarta: Andi Offse, 2006), 117. 
bertentangan dengan norma-norma yang berlaku di masyarakat dan norma-norma agama.

Penyebab utama hilangnya nilai-nilai kebermaknaan PAI dikalangan mahasiswa IAIN Palopo disebabkan arus budaya yang masuk tanpa proteksi sehingga virus pragmatis dan hedonistic yang melekat dalam gaya hidup modernisasi. Senada dengan temuan ini Harvey Cok pernah meramalkan bahwa proses modernisasi melalui tangan iptek tersebut bakal menggeser peran agama dalam mengisi hidup bermakna. ${ }^{20}$ Bahkan Einstein pernah berkata, "Science without religion is blind, religion without science is lame“. Yang artinya, "Pengetahuan tanpa agama adalah buta, agama tanpa pengetahuan adalah cacat".

Kebermaknaan PAI memang benar-benar merupakan motivasi, utamanya bagi umat muslim. Hasrat inilah yang mendasari berbagai kegiatan manusia misalnya bekerja dan berkarya agar kehidupan yang dirasakan berarti dan berharga. Jika keimanan dan ketaqwaan seseorang tinggi, maka akan semakin positif penghayatan keagamaan seseorang dalam kehidupan sehari-hari, sehingga akan mempengaruhi seseorang dalam menghadapi persoalan dirinya dengan lingkungan masyarakat di sekitarnya. Namun berdasarkan hasil penelitian apa yang terjadi dikalangan mahasiswa IAIN Palopo justru berbeda. Modernisasi telah merubah cara pandang mahasiswa mengenai kedudukan agama dalam hidupnya dan keyakinan akan kemampuan dirinya dalam berperilaku serta merta telah terkikis, nilai-nilai spiritual dan keislaman yang disajikan dalam kurikulum PAI justru mengalami penurunan.

Tidak dapat ditampik bahwa representasi mental dan kognitif individu atas realitas juga sangat dibutuhkan. Dengan adanya efikasi diri yang tinggi dalam jangka panjang maka akan mempengaruhi cara-cara sosialisasi yang akan dilakukan serta cara pandang seseorang terhadap kualitas dirinya sendiri, yang baik ataupun yang buruk. Bandura menyatakan bahwa efikasi diri dapat diperoleh, dipelajari, dan dikembangkan dari empat sumber informasi yaitu pengalaman keberhasilan dan pencapaian prestasi, pengalaman orang lain, persuasi verbal,

${ }^{20}$ Abidin Slamet, Fiqih Ibadah (Bandung: CV Pustaka Setia, 1998), 46. 
keadaan fisiologis dan psikologis. ${ }^{21}$ Pada dasarnya, keempat sumber tersebut adalah stimulasi atau kejadian yang dapat memberikan inspirasi atau pembangkit positif untuk berusaha menyelesaikan tugas atau masalah yang dihadapi.

Hipotesis penelitian yang diajukan secara keseluruhan terbukti diterima. Namun temuan ini tidak mampu secara sistematis mengekplorasi semua faktor kebermaknaan PAI, sebagaimana yang dikemukakan Frankl mengenai individu sehat, yaitu individu yang dapat menemukan kebermaknaan hidupnya melalui realisasi nilai-nilai manusiawi. ${ }^{22}$ Sejalan dengan penelitian ini, penelitian yang serupa yang mengkaji makna hidup juga pernah dilakukan oleh Douglas R. May dengan judul penelitian "The Influence of Business Ethics Education on Moral Efficacy, Moral Meaningfulness, and Moral Courage: A Quasi-experimental Study" berdasarkan hasil penelitiannya Douglas R. May menyimpulkan bahwa etika bisnis mampu mempengaruhi kebermaknaan hidup siswa dalam menangani etika kerja. ${ }^{23}$ Dapat dijabarkan bahwa faktor-faktor yang mempengaruhi kebermaknaan hidup seseorang adalah faktor-faktor internal dan eksternal. Faktorfaktor internal meliputi pola fikir, pola sikap, konsep diri, corak penghayatan, ibadah dan kepribadian.

Temuan pada penelitian ini menunjukkan bahwa efikasi diri memiliki persentase yang lebih besar dibandingkan orientasi religiusitas. Temuan tersebut sejalan dengan apa yang pernah disampaikan oleh Bandura dan Wood yaitu efikasi diri merupakan keyakinan terhadap kemampuan seseorang untuk menggerakkan motivasi, sumber-sumber kognitif, dan serang-kaian tindakan yang diperlukan untuk memenuhi tuntutan-tuntutan dari situasi yang dihadapi. ${ }^{24}$ Lebih lanjut penelitian tentang efikasi diri juga pernah dilakukan oleh Fitria Sedjati dengan judul penelitian "Hubungan Antara Efikasi Diri Dan Dukungan Sosial Dengan Kebermaknaan Hidup Pada Penderita Tuberkulosis Paru Di Balai

${ }^{21}$ Bandura, Self-Efficacy: The Exercise of Control, 195.

${ }^{22}$ Schultz P. D., Psychological \& Work Today: An Introduction to Industrial \& Organizational Psychology. (New Jersey: Prentice Hall, 1998).

${ }^{23}$ Douglas R. May Schwoerer Matthew T. Luth E Catherine, The Influence of Business Ethics Education on Moral Efficacy, Moral Meaningfulness, and Moral Courage: A Quasi-Experimental Study (Springer Science Business Media Dordrecht, 2013).

${ }^{24}$ Bandura, Self-Efficacy: The Exercise of Control. 
Pengobatan Penyakit Paru-Paru (BP4) Yogyakarta" dengan hasil penelitian yaitu Ada hubungan positif yang sangat signifikan antara efikasi diri dengan kebermaknaan hidup. Semakin tinggi efikasi diri, makan semakin tinggi kebermaknaan hidup. Semakin rendah efikasi diri maka semakin rendah kebermaknaan hidup. ${ }^{25}$ Dengan berbagai situasi yang dihadapi mendorong seseorang untuk memahami secara mendalam tentang hal-hal yang dianggap sangat penting dan berharga serta memberikan nilai khusus bagi seseorang sehingga dapat menerangkan tentang mengapa seseorang ada yang mengalami kegagalan atau yang berhasil dan layak dijadikan sebagai tujuan hidup.

\section{E. Kesimpulan}

Terlihat bahwa nilai-nilai ajaran agama Islam belum melahirkan kebermaknaan dalam kehidupan masyarakat muslim di Indonesia. Ritual ibadah yang syarat akan makna, hilang tanpa jejak dari para pelakunya. Perilaku keberagamaan yang tampak belum mampu menata pola pikir, pola tindak dan pola rasa hingga kehidupan religiusitas yang ideal terlihat kontradiktif dengan fakta sosial yang ada. Berdasarkan hasil analisis dan uji hipotesisi tentang pengaruh orientasi religiusitas dan efikasi diri terhadap kebermaknaan pendidikan agama Islam yang telah diuraikan sebelumnya, dapat ditarik kesimpulkan yaitu: (1) Orientasi religiusitas berpengaruh terhadap kebermaknaan pendidikan agama Islam, (2) Efikasi diri berpengaruh terhadap kebermaknaan pendidikan agama, (3) Orientasi religiusitas dan efikasi diri secara bersama-sama berpengaruh terhadap kebermaknaan PAI.

Berdasarkan kesimpulan di atas dan dengan memperhatikan keterbatasan dalam penelitian ini, peneliti mengajukan saran agar dapat dijadikan bahan pertimbangan yaitu karena religiusitas dan efikasi diri berhubungan secara signifikan terhadap kebermaknaan pendidikan agama Islam, maka diharapkan agar universitas khususnya IAIN Palopo mampu mengintegrasikan mata kuliah pendidikan agama Islam dengan berbagai aspek yang berhubungan dengan

${ }^{25}$ Fitria Sedjati, "Hubungan Antara Efikasi Diri Dan Dukungan Sosial Dengan Kebermaknaan Hidup Pada Penderita Tuberkulosis Paru Di Balai Pengobatan Penyakit Paru-Paru," Emphati Jurnal Psikolog 02, no. 01 (2013). 
orientasi religiusitas dan efikasi diri, sehingga mahasiswa menjadi termotivasi dan memiliki perencanaan yang matang dan kemampuan evaluasi yang baik.

\section{Daftar Pustaka}

Arifin, H. Muzayyin. "Filsafat Pendidikan Islam," n.d. Accessed November 29, 2017.

Askari, Scheherazade S. Rehman, and Hossein. "How Islamic Are Islamic Countries." Global Economy Journal 10, no. 02 (2010).

Bandura, A. Self-Efficacy: The Exercise of Control. New York: W.H.Freeman and Company, 1997.

Chaplin, J.P. "Kamus Lengkap Psikologi." Accessed November 29, 2017. http://library.um.ac.id/free-contents/index.php/buku/detail/kamus-lengkappsikologi-j-p-chaplin-penerjemah-kartini-kartono-31745.html.

Creswell, John. Riset Pendidikan (Perencanaan, Pelaksanaan, Dan Evaluasi Riset Kualitatif Dan Kuantitatif. Yogyakarta: Pustaka Pelajar, 2015.

Denis, John McCormick \& Hoekman, Catherine \& Smith,. "Religious Orientation \& Locus of Control in an Australian Open Enrolment Christian School," Mei 2015. Publikasi Online dari : http://www.aare.edu.au/00pap/mcc00072-.htm.

E, Douglas R. May Schwoerer Matthew T. Luth, Catherine. The Influence of Business Ethics Education on Moral Efficacy, Moral Meaningfulness, and Moral Courage: A Quasi-Experimental Study. Springer Science Business Media Dordrecht, 2013.

E.W, Priska N. \& Henny. "Orientasi Religius Pasangan Dewasa Muda Kristen Yang Mengalami Ketidakharmonisan Pernikahan." ARKHE: Journal Ilmiah Psikologi Tahun 9, no. 2 (n.d.).

Fuad, Nashori. “Orientasi Keagamaan Mahasiswi Muslim Berjilbab.” Psikologika 03, no. No.5 (1998).

Hadi, Sutrisno. Statistik Jilid 2. Yogyakarta: Penerbit Andi, 2000.

Handayani, Nani Sri, and Zahrotul Uyun. "Pengaruh Tingkat Religiusitas Terhadap Kesiapan Menghadapi Perkawinan Mahasantri Pondok Muhammadiyah Hajjah Nuriyah Shabran Surakarta," December 2004. http://publikasiilmiah.ums.ac.id:80/handle/11617/1056.

Harjana dalam Toifur, \& Johana Endang P. "Hubungan Antara Status Sosial Ekonomi, Orientasi Religius, Dan Dukungan Sosial Dengan Burnout Pada Guru Sekolah Dasar Di Kabupaten Cilacap." Sosiohumanika, no. 03 (2003).

P., Schultz, D. Psychological \& Work Today: An Introduction to Industrial \& Organizational Psychology. New Jersey: Prentice Hall, 1998.

Robbert, R.Hogan, \& B.W. Personality Psychology: In the Workplace. Washington DC: American Psychology Association, 2001.

Sedjati, Fitria. "Hubungan Antara Efikasi Diri Dan Dukungan Sosial Dengan Kebermaknaan Hidup Pada Penderita Tuberkulosis Paru Di Balai 
Pengobatan Penyakit Paru-Paru.” Emphati Jurnal Psikolog 02, no. 01 (2013).

Sitiadi, Usman, Usaini dan Akbar, R. Purnomo. Pengantar Statistika. Jakarta: Bumi Aksara, 1995.

Slamet, Abidin. Fiqih Ibadah. Bandung: CV Pustaka Setia, 1998.

Sumanto. Metodologi Penelitian Sosial Pendidikan: Aplikasi Metode Kuantitatif Dan Statistika Dalam Penelitian. Yogyakarta: Andi Offse, 2006.

Ventis, Batson. "Religious Orientation and Meaning in Life: An Exploratory Study," Mei 2015. http://clearinghouse.missouriwestern.edu/manuscripts/172.php.

Winkler-Herman, Jess Feist, Gregory J Feist Dr., Tomi-Ann Roberts. "Theories of Personality," n.d. Accessed November 29, 2017. 